\title{
Turismo em Unidades de Conservação: o Jardim Botânico Benjamim Maranhão, João Pessoa (PB)
}

\section{Tourism in Protected Areas: the Botanical Garden Benjamim Maranhão, João Pessoa (PB, Brazil)}

Ilana Barreto Kiyotani, Fabiana Gomes Sousa, Amada Gama Tavares

\begin{abstract}
RESUMO
Atividades sustentáveis têm se tornado o foco de muitos países, principalmente no que diz respeito aos aspectos econômicos e ambientais. A implantação de Unidades de Conservação, como os Jardins Botânicos, e a realização do turismo nesses ambientes têm se mostrado opções para o alcance da sustentabilidade e da consciência ambiental. O objetivo deste trabalho é apresentar, dentro do contexto das Unidades de Conservação, das Áreas de Preservação Permanente e dos Jardins Botânicos, os usos turísticos do Jardim Botânico Benjamim Maranhão (JBBM), em João Pessoa (PB). A escolha leva em conta sua relevância para a cidade no que diz respeito ao incentivo à consciência ambiental, assim como sua representação de maior área de floresta nativa urbana do País. Foram usadas pesquisas bibliográficas, numa abordagem qualitativa, e visitas in loco ao JBBM. O caso relatado tem proporcionado visitação, lazer e educação a turistas e visitantes. Através das atividades realizadas, majoritariamente trilhas, a consciência ecológica e ambiental é instigada, proporcionando ao visitante maior conhecimento e interatividade com o espaço. No entanto, em relação a suas características ambientais, percebese que o JBBM poderia implementar outras ações, como atividades mais incisivas de interpretação ambiental; parcerias que favoreçam mais visitações e; práticas pedagógicas relacionadas a outros campos de estudo, como sociologia e história. No que tange a práticas turísticas, além do ecoturismo e do turismo pedagógico, poder-se-ia pensar em outros segmentos do turismo, como de aventura; de eventos; científico e; de experiência.
\end{abstract}

KEYWORDS: Turismo; Unidades de Conservação; Jardim Botânico Benjamim Maranhão. 


\begin{abstract}
Sustainable activities have become the focus of many countries, particularly with regard to economic and environmental aspects. The establishment of Conservation Units, such as Botanical Gardens, and the realization of tourism in these environments have presented as options to achieve sustainability and environmental awareness. The aim of this paper is to present, within the context of the Conservation Units, the Permanent Preservation Areas and the Botanical Gardens, the touristic uses of the Jardim Botânico Benjamim Maranhão (JBBM) in João Pessoa (PB). The choice considers its relevance to the city with regard to encouraging environmental awareness, as well as its representation being the biggest urban area of native forest in the country. Library research was used, in a qualitative approach, and also visits to the JBBM. The reported case has provided visitation, recreation and education to tourists and visitors. In all the three activities, mostly trails, the ecological and environmental awareness is instigated, giving visitors a bigger knowledge and interaction with the space. However, in relation to their environmental characteristics, it is noted that the JBBM could implement others actions, such as more forceful activities of environmental interpretation; partnerships that promote more visitations and; pedagogical practices related to other fields of study, such as sociology and history. In terms of tourism practices, in addition to the ecotourism and educational tourism, it is possible to think about other tourism segments, such as adventure; events; scientific and; tourism of experience.
\end{abstract}

KEYWORDS: Tourism; Protect Areas; Jardim Botânico Benjamim Maranhão.

\title{
Introdução
}

A relevância de práticas humanas sustentáveis está sendo bem evidenciada nas últimas décadas. Evidência que se apresenta, por exemplo, pela preocupação com as transformações climáticas e pelo combate de cientistas ambientais e de Organizações Não-Governamentais contra a decisão de alguns países em manter a produção industrial à custa de degradação ambiental.

Diversos países, inclusive o Brasil, têm intensificado a busca pela sustentabilidade, principalmente no que se refere a questões econômicas e ambientais. Para ter êxito nessa difícil missão, no entanto, é preciso educar as gerações atuais e futuras, conscientizando-as sobre a necessidade de preservar os recursos naturais e de buscar a geração de riquezas de forma sustentável, de forma a haver equilíbrio entre produção e manutenção do meio ambiente.

No Brasil, vários são os agentes que buscam o alcance desses objetivos, mantendo a possibilidade de o país ter uma população consciente de seus deveres e fiscalizadora de seus direitos. Dentre esses atores estão os Jardins Botânicos, assim como todas as demais Unidades de Conservação. Atividades desenvolvidas em locais assim, como palestras, aulas de campo e visitas turísticas, são alguns dos instrumentos para tal participação. 
Em João Pessoa (PB), o Jardim Botânico Benjamim Maranhão faz parte da macroestrutura no desenvolvimento das políticas públicas socioeducativas e ambientais. E tem a função de possibilitar, em sua microestrutura, experiências ecológicas a seus visitantes e turistas, através de atividades guiadas, de lazer e de consciência ambiental.

Mas, como o turismo, um dos instrumentos para o alcance da conscientização ambiental, tem sido inserido no contexto do Jardim Botânico Benjamim Maranhão? O objetivo deste trabalho é, portanto, apresentar, dentro do contexto das Unidades de Conservação, das Áreas de Preservação Permanente e dos Jardins Botânicos, os usos turísticos do Jardim Botânico Benjamim Maranhão, mostrando sua relevância para a capital Paraibana e para o incentivo à consciência ambiental.

Para o alcance desse objetivo, foram usadas pesquisas bibliográficas, numa abordagem qualitativa, e trabalhos de campo no Jardim Botânico Benjamim Maranhão, em João Pessoa (PB).

O trabalho está dividido em cinco partes. Primeiramente, uma introdução ao assunto de como o turismo tem sido uma atividade praticada em Unidades de Conservação e mais especificamente em Areas de Preservação Permanente. Em seguida, na segunda parte trata-se da inserção do turismo nesses locais. $\mathrm{Na}$ terceira seção, são apresentados alguns dos usos dos Jardins Botânicos, introduzindo o assunto tema da quarta parte: o turismo no Jardim Botânico Benjamim Maranhão. Por fim, algumas considerações finais sobre a temática são traçadas.

\section{Turismo em Unidades de Conservação}

Desenvolvendo-se principalmente após a Revolução Industrial, o turismo tem ganhado força e conquistado novos espaços mundialmente (IGNARRA, 2003). Em nível nacional, o Ministério do Turismo atribui o desenvolvimento da atividade ao fortalecimento da economia nacional, ao aumento de demanda por viagens e investimentos e à expansão do volume de operações e no exterior (MINISTÉRIO DO TURISMO [MTUR], 2013).

Dentre as várias segmentações do turismo ${ }^{1}$, nota-se uma demanda por atividades que buscam o meio natural - tanto para desfrutar das belezas das paisagens como para a prática de diversas atividades de lazer. Desta forma, em suas configurações atuais, o turismo é excessivamente consumidor de bens naturais e apoia-se no meio ambiente, considerando-o variável fundamental na diferenciação da destinação (SILVA, 2008).

O uso constante, e muitas vezes desordenado, dos ecossistemas para fins de visitações levou a uma tomada de consciência de que seria necessário implementar alguma forma de proteção dessas áreas. Poder-seia assim preservar a fauna e a flora da pesada ação do homem. Essa necessidade recebeu impulso com a criação do Yellowstone National Park, em 1872, nos Estados Unidos. Tal estratégia acabou sendo adotada por outros países, marcando o início à proteção oficial de ecossistemas terrestres (DIEGUES, 2004; MILANO, 2002; MORSELLO, 2001).

No Brasil, a importância da conservação natural confirmou-se com o primeiro Relatório Nacional para a Convenção sobre Diversidade Biológica, 
que mostrou a diversidade de ecossistemas naturais do país, a ponto de ser considerada a nação mais rica em biodiversidade ${ }^{2}$ (MINISTÉRIO DO MEIO AMBIENTE [MMA], 1998). Alguns dos aspectos que motivam a conservação dessa biodiversidade são suas contribuições econômicas, sendo base de produtos alimentares, farmacêuticos, industriais e biotecnológicos; a manutenção dos ciclos ambientais da terra; o valor estético para fins de entretenimento e turismo e; o valor intrínseco, inerente a cada espécie (KINKER, 2002).

No despertar à preservação de suas riquezas naturais e ao resguardo de seu patrimônio biológico, criou-se por meio da Lei no 9.985/00 o Sistema Nacional de Unidade de Conservação da Natureza (SNUC). O Sistema estabelece critérios e normas para a criação, implantação e gestão das Unidades de Conservação. Tornando-se ferramentas fundamentais à preservação dos ecossistemas brasileiros, as Unidades de Conservação (UC) são

espaços territoriais e seus recursos ambientais, incluindo as águas jurisdicionais, com características relevantes, legalmente instituído pelo poder público, com objetivos de conservação e limites definidos, sob regime especial de administração, ao qual se aplicam garantias adequadas de proteção (SNUC, 2000).

Os objetivos centrais do SNUC consistem na conservação da diversidade biológica; utilização sustentável dos recursos naturais; pesquisa científica; geração de emprego e renda às comunidades envolvidas; visitação pública; Educação Ambiental; promoção do ecoturismo ${ }^{3} \mathrm{com}$ serviços de atividades de lazer, recreação e difusão do valor multicultural do ambiente (SNUC, 2000).

Especificamente sobre o objetivo relacionado ao ecoturismo, contido no artigo 4ํㅜㄹ percebe-se que este busca favorecer as condições de sua realização e promover a educação e interpretação ambiental, a recreação em contato com a natureza e o turismo ecológico. A prática responsável dessa atividade em UC's é considerada como

[...] uma alternativa econômica promissora, uma vez que os recursos gerados pela visitação a UC podem vir a apoiar o manejo das unidades, principalmente à criação de empregos e a consequente geração e distribuição de renda para a população das comunidades vizinhas, além de disponibilizar conhecimento e informações ambientais, culturais e históricas captando mais adeptos para conservação (ROCKTAESCHEL, 2006, p.65).

O desejo de fuga do homem dos grandes centros urbanos para se refugiar junto à natureza tem aumentado a escolha por lugares pacatos, sendo as UC's uma frequente escolha. Aquelas com boa infraestrutura turística e com oferta de atividades ecológicas são as que mais se destacam. Rocktaeschel (2006, p.16) afirma que 
de 1999 para hoje, a demanda pela visitação em UC's tem crescido muito, principalmente em razão do ecoturismo. No cenário do desenvolvimento sustentável, essa modalidade de turismo constitui alternativa para a conservação do meio ambiente e inclusão social, por meio da geração de empregos e renda para as populações do entorno das UC's.

O SNUC foi constituído pelo conjunto das Unidades de Conservação federais, estaduais e municipais, de acordo com o disposto na Lei 9.985/00. O conjunto das UC's integrantes do SNUC encontra-se dividido em dois grupos: as Unidades de Proteção Integral e as Unidades de Uso Sustentável, cada um com características específicas.

Faz-se objetivo básico das Unidades de Proteção Integral, "preservar a natureza, sendo admitido apenas o uso indireto dos seus recursos naturais, com exceção dos casos previstos nesta Lei”. Entende-se por uso indireto, aquele que não envolve consumo, coleta, dano ou destruição dos recursos naturais. Esse grupo compreende cinco categorias de manejo, representado por: Estação Ecológica; Reserva Biológica; Parque Nacional; Monumento Natural; e Refúgio de Vida Silvestre (SNUC, 2000).

Já o segundo grupo - Unidades de Uso Sustentável - objetiva "compatibilizar a conservação da natureza com o uso sustentável de parcela dos seus recursos naturais". Uso sustentável relaciona-se à "exploração do ambiente de maneira a garantir a perenidade dos recursos renováveis e dos processos ecológicos, de forma socialmente justa e economicamente viável" (SNUC, 2000). O grupo contempla sete categorias de manejo: Área de Proteção Ambiental; Área de Relevante Interesse Ecológico; Floresta Nacional; Reserva Extrativista; Reserva de Fauna; Reserva de Desenvolvimento Sustentável e; Reserva Particular do Patrimônio Natural (SNUC, 2000).

Dentro das soluções legais disponíveis para a manutenção e proteção dos recursos naturais brasileiros, as Áreas de Preservação Permanentes (APP) podem permear todas as demais acima citadas, limitando alguns de seus usos. Com vistas a compreender tais limitações, explana-se a seguir as possibilidades de atuação dentro de uma APP.

Como elemento integrante das Unidades de Conservação, as Áreas de Preservação Permanente são espaços especialmente protegidos por lei, devido à sua fragilidade e importância socioambiental.

A lei que rege as áreas de proteção de flora do Brasil e discursa sobre APP - o Código Florestal - provém da recente Lei no 12.651 , de maio de 2012 e revogou o antigo Código Florestal de 1965. De acordo com o Art. 3o, $\S$ II deste código, as Áreas de Preservação Permanentes dizem respeito a:

área protegida, coberta ou não por vegetação nativa, com a função ambiental de preservar os recursos hídricos, a paisagem, a estabilidade geológica e a biodiversidade, facilitar o fluxo gênico de fauna e flora, proteger o solo e assegurar o bem-estar das populações humanas (BRASIL, 2012). 
Segundo as diretrizes da lei, as APP's têm o objetivo de proteger a biodiversidade e os recursos hídricos, assim como, a erosão do solo e promover o desenvolvimento sustentável ${ }^{4}$.

A normatização é bastante rígida, não permitindo alterações de suas matas ou qualquer outra forma de interferência na vegetação nativa e na vida dos animais que habitam o seu interior. Elas devem ser mantidas intactas e protegidas com a vegetação natural, pois assumem importância fundamental para o almejado desenvolvimento sustentável.

Em consonância com esta lei, presume-se que as APP's têm o seu uso exclusivo para a preservação de espécies vegetais e animais nativos, conservação dos recursos hídricos nacionais e manejo sustentável do solo, Educação Ambiental ${ }^{5}$, pesquisas científicas e atividades ecoturísticas.

O Art. $3^{\text {o }}$ considera as atividades ecoturísticas e as pesquisas científicas como de baixo impacto, sendo possível a implementação de trilhas para o desenvolvimento do ecoturismo e, consequentemente, a disseminação da Educação Ambiental. No Art. 9º, fica permitido o acesso de pessoas para a realização de tais atividades. No entanto, o uso público destas áreas deve estar vinculado a um planejamento sustentável da atividade ecoturística, respeitando o plano de manejo do local e suas especificidades.

\section{Inserção do Turismo em Áreas de Preservação Permanente}

Segundo o Código Florestal, as APP's devem limitar o fluxo de pessoas, sendo permitida a realização de atividades consideradas de baixo impacto, como visitação ${ }^{6}$, ecoturismo e Educação Ambiental. Elas podem colaborar para a preservação, uma vez que os visitantes se aproximam, percebem e valorizam os aspectos ambientais; auxiliam na manutenção, através de recursos oriundos da visita, e podem contribuir para uma melhor gestão, ao analisar maneiras de adequar as necessidades dos visitantes às do ambiente de forma harmônica para todo o conjunto.

Os ambientes naturais são relevantes motivadores para a prática do turismo, que se utiliza das atividades destacadas para promover a seus usuários bem-estar e lazer e aos envolvidos, geração de lucro (FUNARI e PINSKY, 2003). Para que tais atividades sejam praticadas sem causar prejuízos ao ambiente, de modo que os impactos negativos sejam minimizados, faz-se necessário a implantação de um planejamento turístico, visando ao desenvolvimento sustentável, na medida em que esse é considerado fator determinante para o sucesso do turismo independente do ambiente no qual esteja atuando. De acordo com Ruschmann (2004, p.09),

a finalidade do planejamento turístico consiste em ordenar as ações do homem sobre o território e ocupa-se em direcionar a construção de equipamentos e facilidades de forma adequada evitando, dessa forma, os efeitos negativos nos recursos, que os destroem ou reduzem sua atratividade. 
Considera também que o planejamento é fundamental e indispensável para o desenvolvimento turístico equilibrado e em harmonia com os recursos físicos, culturais e sociais das regiões receptoras. Desta forma, evita-se que o turismo destrua as bases que o fizeram existir (RUSCHMANN, 2004). Para Molina (2001), o planejamento turístico de ambientes naturais deve estar orientado para a sustentabilidade dos recursos, levando em consideração as questões ecológicas do local.

Em áreas protegidas, um dos elementos do planejamento é o estudo de Capacidade de Carga Recreativa (CCR), definida como "o número máximo de pessoas que podem utilizar um local sem uma alteração inaceitável no ambiente físico e sem o declínio inaceitável na qualidade da experiência do visitante" (MATHIESO; WALL, 1982 apud WILLIAMS; GILL, 2001, p. 246).

Os números revelados no estudo da CCR apresentam aos gestores desses ambientes compromissos e responsabilidades em desenvolver exercícios com base nos limites do ambiente. Assim, provoca-se no visitante maior grau de satisfação, motivação em retornar ao lugar e mais conforto durante as atividades.

Observa-se ainda a importância das diretrizes para a visitação em áreas protegidas, propostas pelo Ministério do Meio Ambiente (MMA), como forma de implantar corretamente as atividades. Dentre as várias diretrizes propostas pelo órgão, neste trabalho são apresentadas aquelas aplicadas aos órgãos gestores de Unidades de Conservação, como a interpretação ambiental como elemento da educação, a condução dos visitantes e as diretrizes para as caminhadas como atividade ecoturística.

A interpretação ambiental atua como uma atividade educativa que se propõe a revelar significados e inter-relações por meio de uso de objetos originais, do contato direto com o recurso e de meios ilustrativos. Ou seja, vai além da simples comunicação de informação literal (TILDEN, 1957). Através do esforço para que haja esta comunicação especial, o patrimônio natural pode ser compreendido de forma mais ampla, de modo a gerar consequente respeito por parte do visitante (BIESEK; CARDOZO, 2012).

De acordo com Silva (2012), a Interpretação Ambiental (IA) objetiva revelar os significados dados a determinado lugar a seus visitantes. Para isso, é preciso que a primeira etapa seja o proporcionar o entendimento. Visa, portanto, a sensibilizar sobre o ambiente natural em que o visitante se encontra e, em seguida, focar na necessidade e nas formas de se preserválo. Dessa forma, a IA pode exercer um papel introdutório à Educação Ambiental.

É por isso que se diz que é uma atividade persuasiva, ao buscar convencer acreditar ou levar a mudar de atitude. É aí que entra a parte de sensibilização, de modo a levar a audiência a desenvolver certas crenças. No entanto, não se pode negligenciar a relevância de que os intérpretes façam uso de mensagens persuasivas, de forma simples e provocante, mas criativa (SILVA, 2012).

Sendo assim, com o uso da imaginação, o visitante não tem apenas uma visita ao ambiente natural, e sim uma vivência, ampliando sua 
compreensão e seu contato, aumentando a possibilidade da valorização e entendimento da "importância daquele ambiente não apenas para o turismo ou a comunidade em que ele está inserido, mas e, sobretudo em se tratando de patrimônio ambiental, também para toda a sociedade" (BIESEK e CARDOZO, 2012, p.115). Assim, o lugar é revelado de forma a desenvolver pensamentos e atitudes de proteção, ou seja, conservação e preservação do meio ambiente.

Neste processo, a IA pode ser desenvolvida de formas diferentes. Segundo Santos e Alamo (2011), há basicamente três:

a) Interpretação Personalizada, na qual se realizam técnicas como visitas guiadas e anúncios de empresas e concessionárias;

b) Centro de Visitantes e EcoMuseus, que faz uso de exposições e mensagens interpretativas;

c) Meios Pessoais sobre o Terreno, que usam técnicas relacionadas a painéis com mensagens e informações.

Em todas suas técnicas, objetivos e formas possíveis, entende-se que o simples conhecer conceitos sobre conservação ambiental não é suficiente. É preciso atores capacitados e direcionados para essa atividade, de modo a atender aos objetivos da Interpretação Ambiental. Além disso, é necessário planejamento para escolha das técnicas mais adequadas para cada caso e 0 esforço para que o público-alvo conheça as ações.

Nesse sentido, Biesek e Cardoso (2012, p.117) afirmam que a IA é uma "forma de planejar a visitação, e uma forma eficiente, pois proporciona todas as vantagens da preservação do patrimônio agregando uma experiência turística muito mais relevante para o visitante".

Conforme observado, através de técnicas, inclusive da Interpretação Ambiental, há possibilidades da inserção do turismo em APP's através do segmento do ecoturismo, atividade alicerçada na interpretação, na conservação e na sustentabilidade. O segmento pode proporcionar a conciliação equilibrada da visitação, do turismo, da educação e do meio ambiente, além de promover a interpretação ambiental, trabalhada por condutores e monitores, transmitindo informações, realizando atividades educativas, jogos, dinâmicas e experiências vivenciais.

No Brasil, diversas UC's já abrigam o turismo devido à motivação dos visitantes para o contato com esses ambientes. Alguns exemplos de uso desses espaços pela atividade turística são o Parque Nacional Iguaçu (PR), bastante frequentado e reconhecido internacionalmente, o Parque Nacional Marinho de Fernando de Noronha (PE) e o Parque Nacional da Chapada Diamantina (BA). Todos situados em área de proteção integral.

Fazendo um recorte para o uso turístico de APP, alguns Jardins Botânicos, que ocupam espaços situados nesse tipo de área protegida, ofertam atividades ecoturísticas, como trilhas interpretativas. 


\title{
Jardins Botânicos e seus Usos
}

Assim como outros ambientes naturais, os Jardins Botânicos participam da estratégia de conservação. Isso porque seus objetivos são: preservar, proteger espécies silvestres raras ou ameaçadas de extinção; resguardar espécies econômica e ecologicamente importantes para a restauração ou reabilitação de ecossistemas; realizar, de forma sistemática e organizada, registros referentes ao acervo vegetal; pesquisa científica; lazer e educação (CONSELHO NACIONAL DO MEIO AMBIENTE [CONAMA], 2003).

Segundo o Botanic Garden Conservation International (BGCI), "jardins botânicos são instituições que detêm coleções documentadas de plantas vivas para fins de pesquisa científica, conservação, exibição e educação" (BGCl, 2013).

Já o Conselho Nacional do Meio Ambiente (CONAMA), traz uma definição mais abrangente em seu Art. 1ํㅡㅇ com inclusão de novos parâmetros para essas áreas, entendendo-as como:

\begin{abstract}
Área protegida, constituída, no seu todo ou em parte, por coleções de plantas vivas cientificamente reconhecidas, organizadas, documentadas e identificadas, com a finalidade de estudo, pesquisa e documentação do patrimônio florístico do país, acessível ao público, no todo ou em parte, servindo à educação, à cultura, ao lazer e à conservação do meio ambiente (CONAMA, 2000).
\end{abstract}

Os jardins botânicos nasceram da dedicação de botânicos amadores voltados ao cultivo de plantas, que levavam para seu local de origem as espécies vegetais nativas e exóticas que coletavam, de modo que pudessem ser catalogadas, aclimatadas e disseminadas (REDE BRASILEIRA DE JARDINS BOTÂNICOS [RBJB], 2001). A partir desses trabalhos, ainda no século XVI foram criados os primeiros Jardins Botânicos na Europa, estabelecidos na cidade de Pisa (1543), Pádua (1545) e Montpellier (1598), para o cultivo e estudo de plantas medicinais.

No Brasil, o primeiro jardim botânico foi implantado em Recife, no período da dominação holandesa (1630-1654), e reunia espécimes da flora coletadas durantes as expedições ao sertão nordestino (RBJB, 2013). Os portugueses, por sua vez, começaram a criar jardins botânicos em terras brasileiras somente no século XVIII e início do século XIX. O marco inicial dessa fase foi o Jardim Botânico do Rio de Janeiro, fundado em 1808 por Dom João VI, como jardim de aclimatação. Com o passar do tempo, foram implantados vários outros jardins no País (RBJB, 2013).

Boa parte desses Jardins acompanha a história do país, como é o caso do Instituto de Pesquisa Jardim Botânico do Rio de Janeiro, criado em 1808 e considerado o mais antigo do país em funcionamento ${ }^{7}$. Outros de destaque são o Jardim Botânico da Fundação Zoobotânica de Belo Horizonte (MG), o Jardim Botânico de Inhotim (MG); o Jardim Botânico de São Paulo (SP); o Jardim Botânico de Curitiba $(P R)^{8}$; o Jardim Botânico Plantarum (SP) e, por fim, o Jardim Botânico de Brasília (DF). 
A partir de sua popularização como espaço de contemplação da natureza e de lazer, o homem passou a frequentá-los com mais intensidade e, hoje, esses locais tornaram-se pontos estratégicos de visitação, recebendo grande público. O número de Jardins Botânicos em território nacional é crescente, existindo um total de trinta e seis, de diversos tamanhos e localizados de norte a sul do Brasil. Majoritariamente, pertencem aos governos federais e estaduais (RBJB, 2013).

Apesar de serem constantemente confundidos com os parques comuns, os Jardins Botânicos se diferem daqueles por possuírem um grande acervo com coleções de plantas ordenadas e classificadas, registradas e documentadas. E ainda, oferecem ao público visitante informações precisas sobre as espécies botânicas, suas origens, utilidades e curiosidade (GADELHA, 2012). Destacam-se principalmente, além de sua importância histórica, cultural e científica, pela grande quantidade de pessoas que os visitam, para fins educativos, turísticos ou recreativos.

Os Jardins tornaram-se grandes instituições propagadoras da Educação Ambiental, ampliando o seu conceito preservacionista e educador. Incorpora, assim, ao seu meio um público maior e mais diversificado, através de programas educativos que envolvem a interpretação ambiental, atividades ecoturísticas e lazer contemplativo.

A Educação Ambiental em Jardins Botânicos é difundida por ferramentas como: palestras, cursos, caminhadas, pequenos eventos de ciências e até mesmo pelo turismo pedagógico, considerando-se a grande frequência de estudantes de outras localidades que visitam tais espaços.

Como forma de propagar a educação, faz-se uso da Interpretação Ambiental, como ferramenta das atividades de campo, incluindo trilhas e caminhadas ecológicas. Essas atividades visam estimular o público ao entendimento do ambiente natural através de uma experiência direta, demonstrando fenômenos naturais, seus significados e revelações. $E$ ainda, busca interagir, despertar e desenvolver no visitante o sentimento de pertencimento, o prazer pelo espaço ao qual se encontra e a conscientização ambiental (PAGANI et. al.,1999).

A interpretação ambiental está sendo cada vez mais difundida em ambientes naturais. Vem sendo bastante utilizada pelas atividades ecoturísticas, principalmente nos percursos de trilhas interpretativas ${ }^{9}$, atividades frequentes em Jardins Botânicos, sobretudo naqueles que se encontram em reservas florestais.

O uso do ecoturismo em meio a Jardins Botânicos é atualmente uma prática muito empregada para alcançar as finalidades da Educação Ambiental da instituição, pois esses espaços oferecem perfeitas condições para o desenvolvimento desse segmento do turismo. Dentre as atividades, percebe-se que as mais adequadas e difundidas nos jardins botânicos são aquelas direcionadas a observação de aves, da fauna e da flora em seu habitat natural; assim como as trilhas interpretativas (VASCONCELLOS, 1997).

As trilhas também são recursos que ofertam um tipo de lazer especializado, visto que 0 visitante interage com 0 meio através de 
atividades dinâmicas e da observação da diversidade natural. Quando bem elaboradas, tornam-se mecanismos de propagação do bem-estar e da saúde, porque faz seus participantes respirarem um ar mais puro, contemplarem a natureza ao seu redor, além de dar a oportunidade de meditação e fuga da conturbação do dia-a-dia, estimulando-os a valorar o ambiente natural e retornar a este outras vezes.

\section{Jardim Botânico Benjamim Maranhão}

Dentre os Jardins brasileiros, o Jardim Botânico Benjamim Maranhão (JBBM), localizado em João Pessoa, capital do Estado da Paraíba, é relativamente recente. Ele já nasceu voltado para a flora nativa de Mata Atlântica, estando inserido numa reserva desse bioma.

Em 1996, o Instituto Brasileiro do Meio Ambiente e dos Recursos Naturais Renováveis (IBAMA) lançou um projeto para transformar a área então denominada Mata do Buraquinho em um Jardim Botânico. O intuito era preservar e abrir espaço para estudos e pesquisas. No entanto, o projeto não obteve sucesso. Em agosto de 2000, foi assinado o Decreto Estadual no. 21.264 de criação do Jardim Botânico de João Pessoa, com 329,39 hectares, recebendo o nome Jardim Botânico Benjamim Maranhão (BRASIL, 2000; PARAÍBA, 2000).

A inauguração ocorreu em março de 2002, sendo mantido pela Superintendência de Administração do Meio Ambiente (SUDEMA), para atividades que envolvam preservação, pesquisa científica, Educação Ambiental e lazer contemplativo. Também fazem parte a implementação de ações de manejo, monitoramento ambiental, pesquisas relacionadas com a maior área de floresta nativa urbana do País, considerada por muitos especialistas um grande banco genético de espécies da Mata Atlântica (GADELHA, 2012).

Implantado em Área de Preservação Permanente, conhecida como Mata do Buraquinho, o JBBM está localizado mais precisamente a sudoeste do centro urbano de João Pessoa, no litoral do Estado da Paraíba, a uma altitude média de 45 metros, na formação geológica do Baixo Planalto Costeiro, Grande Grupo Barreiras (BARBOSA, 1996).

Segundo Andrade-Lima e Rocha (1971), a reserva constitui-se como vegetação típica das florestas pluviais costeiras nordestino-brasileiras (SUDEMA, 2003). Seus 515ha e importância ambiental tornaram-no um dos principais remanescentes de Mata Atlântica do Estado, possuindo ainda trechos fechados e exuberantes, estimulando a contemplação (Figuras $1 \mathrm{e}$ 2). Passou por alguns incêndios e por retirada de madeira, alterando, em parte, sua vegetação (GADELHA; SANTOS, 2002). Mas ainda se encontra bem conservado, sendo a reserva que representa a maior área de floresta nativa urbana do País (CARVALHO; ALMEIDA, 2001). 


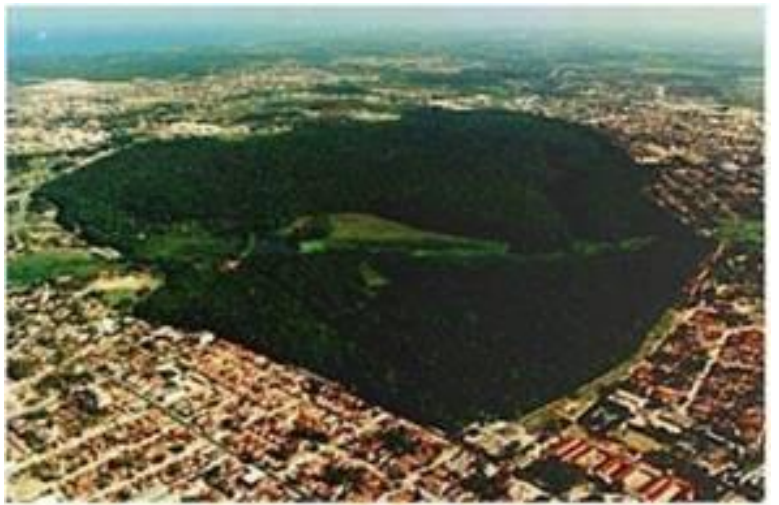

Figura 1: Vista aérea da Reserva do Buraquinho. Fonte: Arquivos do JBBM. Figure 1: Aerial view of the Reserva do Buraquinho. Source: Files of the JBBM.

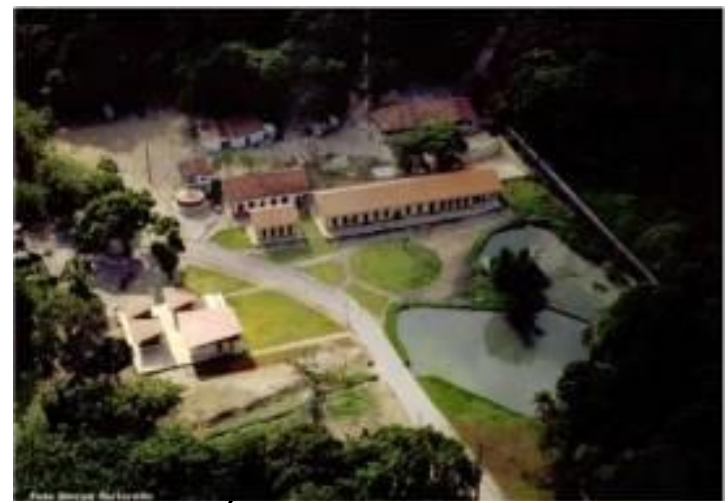

Figura 2: Área de uso público do JBBM Fonte: Arquivos do JBBM.

Figure 2: Public use area of the JBBM. Source: Files of the JBBM.

A reserva está dividida em três áreas. Duas delas estão sob a administração de órgãos públicos: a SUDEMA, na esfera estadual, respondendo pela maior área na qual está inserido o Jardim Botânico; e o IBAMA, de cunho federal. Uma terceira parte consiste em propriedade privada (Figura 3).

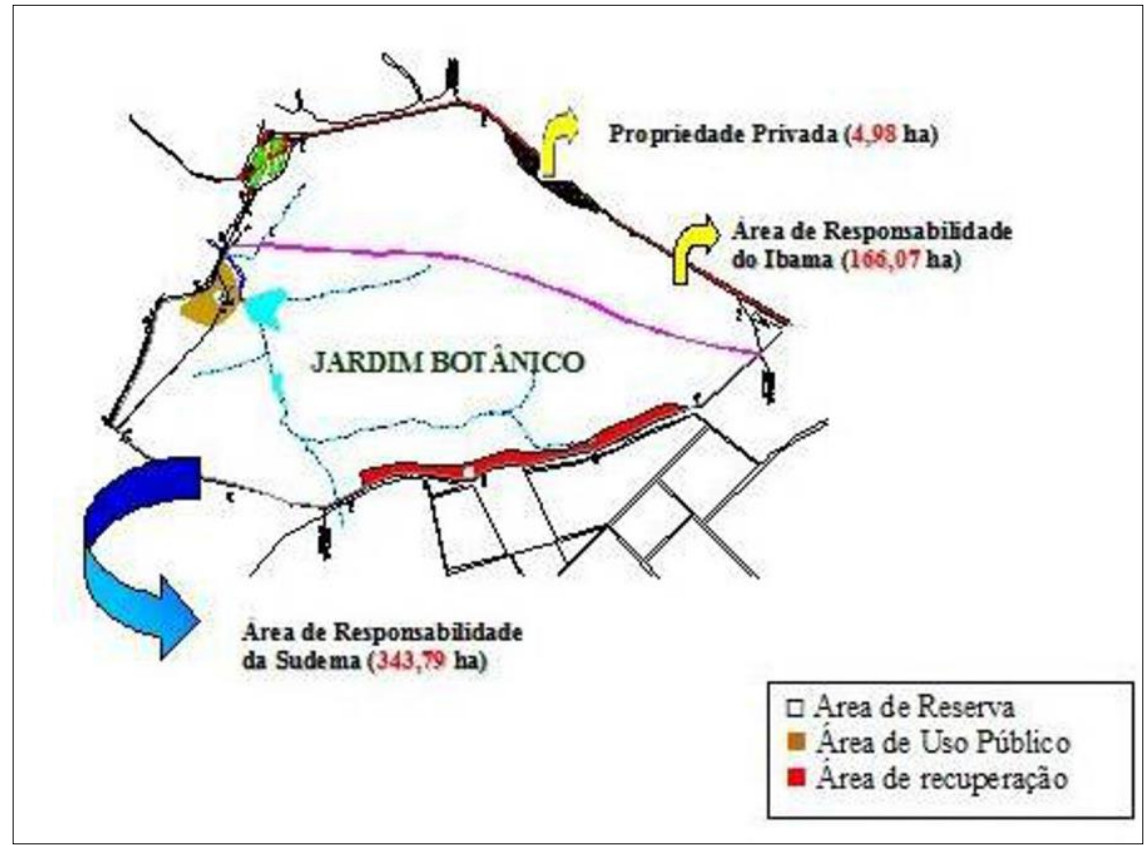

Figura 3: Mapa esquemático da Reserva do Buraquinho. Fonte: Gadelha Neto (2012). Figure 3: Schematic map of the Reserva do Buraquinho. Source: Gadelha Neto (2012).

A missão do JBBM refere-se a promover a conservação da Mata Atlântica do Nordeste, coordenando ações e programas de pesquisa e Educação Ambiental, além de desenvolver e manter coleções documentadas de plantas da Mata Atlântica, e outros espécimes botânicos apropriados à zona climática do Nordeste (LUCENA, 2002).

De acordo com Pereira (2004), o JBBM tenta desenvolver determinadas ações para a concretização desse intuito, tais como: 
- incentivo ao estudo da ecologia das populações;

- incentivo à conservação genética de espécies nativas superexploradas, da taxonomia de grupos selecionados e florística de áreas prioritárias para a conservação;

- planejamento ambiental;

- polinização de sistemas reprodutivos, da biologia e tecnologia de sementes, da etnobotânica, da horticultura

- apoio à educação, à bioinformática, ao georreferenciamento e à bioética;

- estabelecimento de dados ambientais;

- realização de ações de sustentabilidade ecológica e ambiental.

Segundo Lucena (2002), o JBBM foi o primeiro a de fato implantar todas as normas estabelecidas no Manual Técnico Darwin para Jardins Botânicos. Pois, realizou pesquisas, incentivou a conservação, proporcionou atividades de Educação Ambiental e de lazer contemplativo. Assim, tornou pública a importância das plantas pertencentes ao local.

Com isso, destaca-se a importância socioambiental do JBBM para a cidade de João Pessoa. Além de ser privilegiado por situar-se em Área de Preservação Permanente de resquício do bioma da Mata Atlântica, considerado um dos mais ricos conjuntos de ecossistemas em termos de diversidade biológica do planeta (GADELHA, 2004). Fator este de grande atratividade para o público, ao ser possível desfrutar da valia que tem esse ecossistema. Por outro lado, recai sobre o Jardim uma responsabilidade ainda maior de preservar estes recursos.

A notória importância ambiental traduz-se pela preservação de vários fatores ambientais, diretamente ligados à reserva e indiretamente à cidade. Dentre todos, destacam-se: conservação de flora, servindo tanto para a alimentação dos animais como para o homem; indústria; medicina; produção de fármacos; ornamentação e abrigo para os animais da reserva; purificação do ar; regulação do clima e pluviosidade.

No interior do Jardim, observa-se ainda outra contribuição da flora. Refere-se à proteção do manancial existente, através da vegetação de mata ciliar, purificando e oxigenando as águas do rio Jaguaribe, e protegendo o solo contra a erosão e assoreamento do rio.

São exemplares da flora presente no Jardim a Sucupira, Cupiúba, Embiriba, Gitaí, Pau-Brasil, Macaíba, Murici e Embaúba. Além da flora, os animais são fortes atrativos do jardim, principalmente para o público infantil.

Quanto à fauna, o Jardim abriga centenas de espécies, distribuídas entre as categorias de mamíferos, aves, répteis, anfíbios e peixes. São comumente encontrados no local o bicho preguiça, saguis, aranhas, pássaros, borboletas e rãs, e ainda se sabe da existência de cobras como jiboia e caninana, de jacarés da espécie coroa e do papo amarelo, de tamanduá mirim, de raposas e de cutias. 
Além de prover benefícios ambientais para a sociedade pessoense, como purificação do ar, aumento da umidade, absorção de $\mathrm{CO}^{2}$, proteção de águas do subsolo e autodepuração do Rio Jaguaribe, o JBBM se apresenta como um centro educador. Em suas atividades, trabalha-se a educação, a interpretação e conscientização ambiental, utilizando como recurso atividades de trilhas, palestras e demonstração dos espaços e seus aspectos históricos ao visitante.

Sendo a pesquisa mais uma de suas ações de educação e ensino, o JBBM, em conjunto com a Universidade Federal da Paraíba, realiza ações baseadas na catalogação da flora e na manutenção de coleções dos espécimes vegetais do ecossistema, além de espécimes botânicos apropriados à zona climática do Nordeste.

Quanto à Educação Ambiental, o JBBM constitui-se em local de usufruto das escolas para fins educativos e recreacionais. Isso ocorre principalmente quando os alunos têm a visita ao Jardim como aula de campo, podendo conhecer, questionar, reconhecer, interagir e sentir com a natureza. Dessa forma, tanto o aprendizado como a valorização dos recursos naturais são facilitados.

Outro aspecto de relativa importância para a cidade é o sociocultural, na medida em que o Jardim, em parceria com a SUDEMA, busca a melhoria da qualidade de vida das comunidades circunvizinhas, por meio de projetos socioambientais. O objetivo é envolvê-las no processo de socialização, aprendizado e reconhecimento do espaço, como parte de sua cultura, até mesmo porque o Jardim faz parte de sua história. Um exemplo é o Projeto Ecomunidade, desenvolvido junto à comunidade São Rafael, visando à aproximação das crianças ao Jardim e o despertar para a Educação Ambiental. Elas participam através de encenações teatrais, confecção e manuseio de brinquedos feitos de garrafas pets e de uma horta vertical do mesmo material, além de outras atividades.

Por fim, cita-se seu potencial turístico, que não vem sendo apreciado como poderia. $\mathrm{O}$ Jardim não tem sido lançado como atrativo da cidade, não havendo trabalhos em conjunto ao trade turístico da cidade. Mesmo assim, é perceptível que o espaço possui significativo valor paisagístico e turístico, pois seu rico patrimônio natural pode ser fator de grande atratividade para turistas, advindos dos mais diversos lugares.

Possui uma estrutura física na área de uso público, servindo de apoio ao visitante e a seus funcionários, compreendido por um complexo arquitetônico histórico, paisagístico e funcional. Algumas edificações são datadas da década de 1920, e são utilizadas pelo sistema de abastecimento de água. Restauradas e transformadas interiormente, com exceção do Museu da Água, essas edificações abrigam alguns departamentos do Jardim, como a sede da Administração, o Laboratório de Botânica, e a Biblioteca Espaço Verde.

Nos casarões históricos, destinados à visitação pública, encontram-se instalados ambientes como a sala do PRODETUR ${ }^{10}$, o auditório, a sala de exposição e a sala de oficinas. Ainda há um centro de visitantes e o Batalhão da Polícia Militar Ambiental, que é responsável pela segurança e fiscalização da área e do entorno. 
O Jardim Botânico Benjamim Maranhão conta com uma estrutura administrativa organizacional representada por uma equipe de trabalho relativamente pequena, constituída por: Diretoria; Setor da Botânica; Setor de Paisagismo; Setor de Apoio Técnico; Setor de Manutenção e Limpeza; Setor de Agendamentos e Informações e; uma equipe de estagiários, com estudantes de cursos de Pedagogia, Turismo e Biologia.

\section{Atividades turísticas desenvolvidas no Jardim Botânico de João Pessoa}

A visitação e o turismo desenvolvidos no JBBM estão em consonância com seu plano de manejo (SUDEMA, 2003), que dispõe que a visitação e Educação Ambiental são desenvolvidas com o objetivo de estimular o uso do Jardim Botânico e de seus elementos pelas escolas da região, por outras instituições educacionais e pelo público visitante em geral (Ver Figura 4). Uma das finalidades destas atividades é sensibilizar o público, em relação às questões ambientais, de modo a envolver a sociedade no processo de participação da preservação do Jardim Botânico. Esta sensibilização é trabalhada por meio das atividades de trilhas interpretativas que utilizam como recurso fundamental interpretação e Educação Ambiental, desenvolvidas pelos condutores ambientais, ao longo dos percursos.
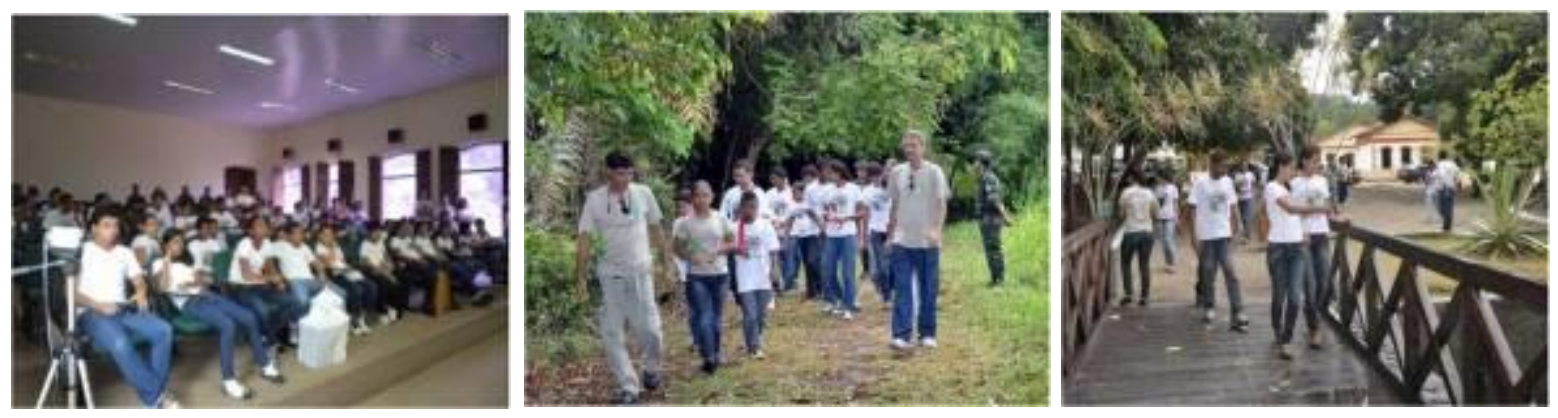

Figura 4: Palestra, trilha e visitação, respectivamente. Fonte: direta.

Figure 4: Lecture, track and visitation, respectively. Source: Researchers Files.

Atualmente, o Jardim Botânico Benjamim Maranhão conta com um total de doze trilhas (Figura 5). A nomenclatura das trilhas faz referência a elementos raros ou de grande importância da flora e fauna local, assim como remete aos nomes tradicionais e históricos da Mata do Buraquinho. Todos os percursos são efetuados com o acompanhamento do condutor, caracterizando-se como trilhas guiadas. Quanto ao grau de dificuldade, são observados três níveis de intensidade:

1. Fácil: destina-se a todos os visitantes, especialmente às pessoas da terceira idade e deficientes físicos, sendo necessária apenas boa saúde;

2. Moderada: deve-se levar, em consideração, o comprimento da trilha, bem como, os obstáculos naturais, requerendo um bom preparo físico dos participantes;

3. Difícil: nesta situação exigem-se habilidades específicas, associadas a um melhor condicionamento físico, devido às características 
naturais e qualidade topográfica do terreno. Destina-se principalmente aos amantes do Traking (GADELHA, 2006).

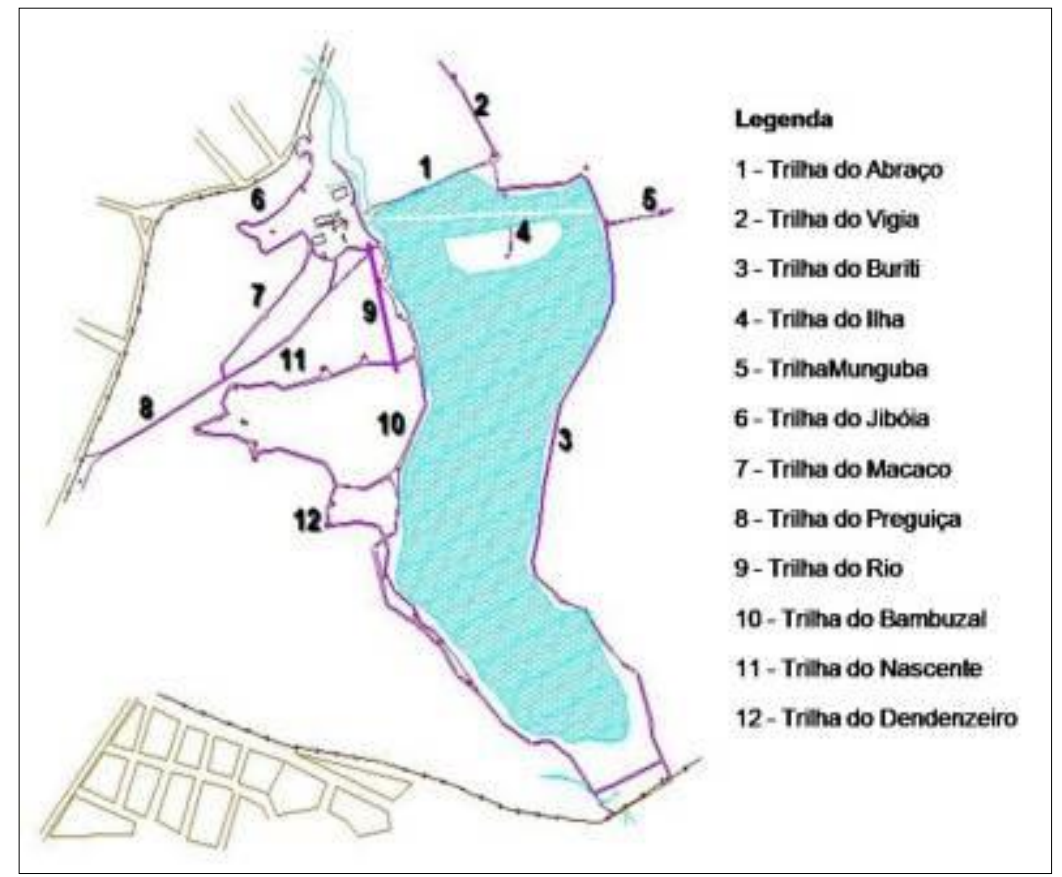

Figura 5: Representação esquemática das principais trilhas do JBBM.

Fonte: Gadelha (2006). Adaptado pelas autoras.

Image 5: Schematic representation of the main tracks of the JBBM.

Source: Gadelha (2006). Adapted by the authors

Gadelha (2006) esboçou o grau de dificuldade relativo às doze trilhas interpretativas do JBBM (Tabela 1).

Cada trilha possui suas características particulares, e seu nome (Tabela 2) está relacionado a alguma destas (GADELHA, 2006):

Tabela 1: Trilhas ambientais interpretativas do Jardim Botânico Benjamim Maranhão.

Table 1: Environmental interpretive trails of the Jardim Botâncio Benjamin Maranhão.

\begin{tabular}{|c|c|c|c|c|}
\hline $\begin{array}{c}\text { Nome da } \\
\text { Trilha }\end{array}$ & Comprimento & Forma & $\begin{array}{c}\text { Grau de } \\
\text { Dificuldade }\end{array}$ & $\begin{array}{c}\text { Duração do } \\
\text { Percurso }\end{array}$ \\
\hline Rio & 294 & Linear & Fácil & $30 \mathrm{~min}$. \\
\hline Preguiça & 335 & Linear & Moderado & $30 \mathrm{~min}$. \\
\hline Buriti & 1533 & Linear & Moderado & $01 \mathrm{~h} 00 \mathrm{~min}$ \\
\hline Ilha & 162 & Linear & Moderado & $15 \mathrm{~min}$. \\
\hline Bambuzal & 1527 & Linear & Moderado & $01 \mathrm{h00min}$ \\
\hline Jiboia & 340 & Semi-circular & Moderado & $20 \mathrm{~min}$. \\
\hline Vigia & 728 & Linear & Moderado & $30 \mathrm{~min}$. \\
\hline Macaco & 318 & Linear & Moderado & $15 \mathrm{~min}$. \\
\hline Abraço & 255 & Linear & Moderado & $15 \mathrm{~min}$. \\
\hline Munguba & 161 & Linear & Moderado & $30 \mathrm{~min}$. \\
\hline Dendezeiro & 595 & Linear & Moderado & $15 \mathrm{~min}$. \\
\hline Nascente & 1037 & Semi-circular & Difícil & $50 \mathrm{~min}$. \\
\hline
\end{tabular}


Tabela 2: Características particulares das trilhas ambientais interpretativas.

Table 2: Special Features of environmental interpretive trails.

\begin{tabular}{|c|c|}
\hline $\begin{array}{l}\text { Trilha do } \\
\text { Rio }\end{array}$ & $\begin{array}{l}\text { de pequena extensão interligando as duas margens do Rio Jaguaribe. } \\
\text { Propicia ao visitante uma visão mais ampla da mata, do açude do Buraquinho } \\
\text { e algumas espécies nativas como a Copiúba e Sambaqui. Uma trilha aberta, } \\
\text { com incidência solar durante todo o dia e de fácil deslocamento. }\end{array}$ \\
\hline $\begin{array}{l}\text { Trilha da } \\
\text { Preguiça }\end{array}$ & $\begin{array}{l}\text { grande ocorrência do Bicho Preguiça, o mais ilustre e cativante animal da } \\
\text { fauna local. Encontra-se uma vegetação bem variada, desde gramíneas a } \\
\text { grandes árvores de Imbaúba, prediletas das preguiças; observam-se também } \\
\text { poços Amazonas, tornando a trilha ainda mais interativa. }\end{array}$ \\
\hline $\begin{array}{l}\text { Trilha do } \\
\text { Buriti }\end{array}$ & $\begin{array}{l}\text { apresenta grande diversidade biológica pelo seu longo percurso, observando } \\
\text { as várias espécies de fungos, as pequenas briófitas, epífitas e conglomerados } \\
\text { de buritis, situados em área bastante alagada. O lago das ninféias, juntamente } \\
\text { com os Ipês, Sucupira, Jitaí, dentre outras plantas atribui ao visitante variação } \\
\text { florística, sons e aromas únicos. }\end{array}$ \\
\hline $\begin{array}{l}\text { Trilha da } \\
\text { Ilha }\end{array}$ & $\begin{array}{l}\text { originou-se a partir das escavações e alargamentos do leito do Rio Jaguaribe. } \\
\text { Este recanto preservado pelo verde constitui-se principalmente de refúgio } \\
\text { para desova de jacarés. }\end{array}$ \\
\hline $\begin{array}{l}\text { Trilha da } \\
\text { Munguba }\end{array}$ & $\begin{array}{l}\text { caracteriza-se por manter espécies arbóreas como o Sambaqui, Cavaçú, } \\
\text { Embiriba, Amescla, além da grandiosa Munguba. }\end{array}$ \\
\hline $\begin{array}{l}\text { Trilha da } \\
\text { Jibóia }\end{array}$ & $\begin{array}{l}\text { embora pequena, mantém, em paralelo à sua extensão, variadas imagens } \\
\text { com a presença de um poço, dois pequenos lagos artificiais, troncos caídos, } \\
\text { além da abundante serrapilheira depositada no solo, dando aspecto de } \\
\text { selvagem e abrigo para as suntuosas jibóias. Na vegetação destacam-se as } \\
\text { Paqueviras, Angelim e mangueiras. }\end{array}$ \\
\hline $\begin{array}{l}\text { Trilha do } \\
\text { Macaco }\end{array}$ & $\begin{array}{l}\text { possui essa denominação a partir de relatos de funcionários e caminhantes, } \\
\text { ao se depararem casualmente com primatas habitantes dessa área. Este } \\
\text { trecho de trilha dava acesso à histórica estrada dos macacos, atualmente } \\
\text { conhecida por Avenida Dom Pedro II. A trilha mantém uma variação florística } \\
\text { expressa pelo Cavaçú, Murici, Viuvinha, dentre outras. }\end{array}$ \\
\hline $\begin{array}{l}\text { Trilha do } \\
\text { Vigia }\end{array}$ & $\begin{array}{l}\text { funcionava como rota de acesso para a Avenida Dom Pedro II.Em sua } \\
\text { extremidade com esta avenida, encontra-se a histórica casa do vigia, atual } \\
\text { rancho da } 24^{a} \text { Companhia de Policiamento Florestal. Na sua trajetória } \\
\text { observam-se inúmeros e atraentes bambuzais, assim como a flora lenhosa } \\
\text { representada pelo Cocão, Amescla, pau de Jangada, Sapucaia. É um trecho } \\
\text { que sofreu bastante interferência do homem, percebível pela erosão do solo e } \\
\text { clareiras na vegetação. }\end{array}$ \\
\hline $\begin{array}{l}\text { Trilha do } \\
\text { Abraço }\end{array}$ & $\begin{array}{l}\text { sua pequena extensão abriga consideradas variações na paisagem com vista } \\
\text { para dois poços Amazonas, além de vastos bambuzais recobrindo parte de } \\
\text { sua extensão. Entretanto o que chama a atenção do visitante é a fabulosa } \\
\text { Lenda do Abraço, entendível a partir da observação acerca do entrelaço entre } \\
\text { duas espécies da flora local: a Gameleira e o Dendezeiro, formando um } \\
\text { "apertado abraço". Tornou-se um dos locais mais requisitados pela visitação. }\end{array}$ \\
\hline $\begin{array}{l}\text { Trilha do } \\
\text { Bambuzal }\end{array}$ & $\begin{array}{l}\text { segunda trilha mais longa, seduz o visitante ao encontrar densos bambuzais } \\
\text { formando verdadeiros corredores naturais e cenográficos. Além disso, os } \\
\text { poços Amazonas e a atrativa flora, a exemplo das Paqueviras, são destaque } \\
\text { no verde da mata e pontos de parada para observação. }\end{array}$ \\
\hline $\begin{array}{l}\text { Trilha da } \\
\text { Nascente }\end{array}$ & $\begin{array}{l}\text { observam-se variações topográficas, exigindo-se habilidades específicas e um } \\
\text { bom condicionamento físico, o que a torna propícia aos amantes do Traking. } \\
\text { Sua importância refere-se ao fato de abrigar nascentes históricas como a do } \\
\text { Buraquinho, que mais tarde doou seu nome para a mata. A vegetação desta } \\
\text { trilha é composta por árvores de grande porte como a Sapucaia, o Gitaí, a } \\
\text { Munguba; há presença de trepadeiras lenhosas e as plantas frutíferas, } \\
\text { aspectos que prendem a atenção dos visitantes, assim como a pureza da } \\
\text { água que sai das nascentes. }\end{array}$ \\
\hline $\begin{array}{l}\text { Trilha do } \\
\text { Dendezeiro }\end{array}$ & $\begin{array}{l}\text { solo predominantemente argiloso, com área bastante úmida e alagada, } \\
\text { tornando-se intransitável em parte de sua extensão durante quase todo o ano. } \\
\text { Compõem o cenário os antigos e rústicos poços Amazonas e os exóticos } \\
\text { dendezeiros imersos nas áreas alagáveis. }\end{array}$ \\
\hline
\end{tabular}


Todas as atividades de trilhas interpretativas são dirigidas por um condutor ambiental, acompanhado por um policial ambiental, responsável pela segurança do grupo. Tais atividades são desenvolvidas em três momentos. No primeiro, ocorre a recepção do grupo e uma pequena palestra sobre o Jardim, apresentando aspectos históricos, funcionais, ambientais, missão, flora, fauna e normas de conduta a serem observadas durante a permanência no espaço.

A partir dos conhecimentos e informações transmitidas aos visitantes, dá-se início ao segundo momento: o exercício da trilha. O condutor, ao avaliar o perfil do grupo, escolhe o percurso mais adequado, assim como o tempo e a frequência das paradas. Nessa fase da visitação ocorrem, simultaneamente à caminhada, as ferramentas de interpretação ambiental personalizada (SANTOS; ALAMO, 2011). Os guias fazem paradas para sentir o ambiente: percepção climática e sonora, principalmente, onde é enfatizada a função daquele espaço para o equilíbrio térmico e melhora térmica da sua párea de entorno. A explanação sobre os pássaros encontrados no espaço também é dada nestes momentos.

Algumas paradas são realizadas em espécies arbóreas específicas, tanto para explicar sua função (como a alimentícia para alguns animais), quanto para contar sua história: se é originária da Mata Atlântica, se foi introduzida no Brasil, sua relevância dentro da Mata Atlântica, bem como lendas e/ou contos locais e brasileiros. As trilhas do Rio, do Vigia, do Abraço, da Nascente e do Dendezeiro são exemplos de trilhas que fornecem subsídio para contextualizar a história local, do crescimento urbano de João Pessoa e das funções do Rio Jaguaribe e desta área histórica, que é a Mata do Buraquinho, como é mais conhecida na cidade.

Já as trilhas da Preguiça e da Ilha são paradas que permitem inserir informações sobre os animais encontrados ali. Além de falar sobre seus hábitos, os guias também fazem a ressalva da importância na preservação e manutenção da mata, uma vez que muitas preguiças já foram encontradas em plena Avenida Dom Pedro II, que passa na frente do Jardim Botânico, reportando que, sem o seu habitat natural, as condições de vida da fauna podem tornar-se crítica.

Percebe-se que a interpretação ambiental nesse local, além de proporcionar maior conhecimento técnico sobre a Mata Atlântica e algumas espécies da fauna brasileira, também traz ao público informação sobre a cidade de João Pessoa e ainda alguns pontos de cultura popular, uma vez que lendas são contadas durante algumas trilhas. Todos esses mecanismos levam a uma maior aproximação do público com o meio ambiente local, bem como maior conscientização de sua importância. E ainda, há uma valoração dos recursos hídricos, ao fazer-se menção de sua relevância ao equilíbrio térmico e pluvial da cidade e sua função na história de constituição e crescimento da capital paraibana.

O terceiro momento refere-se à análise, pelo condutor, quanto ao grau de satisfação do grupo, bem como aos agradecimentos finais. Nessa ocasião, termina-se o acompanhamento do guia e o visitante fica livre para desfrutar das paisagens do espaço externo, podendo também visitar os 
casarões históricos e a sala de exposição com coleções de sementes, de besouros, de animais empalhados, etc.

A visitação é gratuita e, no caso de grupos acima de dez pessoas, faz-se necessário agendamento junto à administração. $O$ visitante que participa das caminhadas, no entanto, deve obedecer às normas do JBBM, que incluem, por exemplo, o uso de vestimenta adequada (calça comprida e sapatos fechados).

A ocorrência dessas atividades depende muito de fatores climáticos, como o índice de chuvas e a luminosidade natural no interior da mata. No período chuvoso, torna-se inviável a prática de trilhas, visto que o solo fica encharcado, aumentando o risco de acidentes. Quanto à luminosidade, a partir das 16h00, a pouca incidência de luz dificulta a atividade, justificando o último horário de trilha.

\section{Considerações Finais}

A busca por um maior contato com a natureza tem trazido adeptos aos seguimentos do turismo que se utilizam de áreas naturais, sendo que 0 ecoturismo tem recebido certo destaque. Nessa atividade, uma das práticas mais comuns são as trilhas ecológicas, nas quais é importante desenvolver a Educação Ambiental, de forma que, além de proporcionar bem-estar ao visitante, viabilize a consciência ambiental, fundamental à preservação dos recursos naturais.

Como espaços propícios ao desenvolvimento de um turismo sustentável, e tendo neste uma ferramenta para contribuir à conservação do meio ambiente, as Unidades de Conservação tornaram-se atrativas para a prática do ecoturismo. Dentro dessa abrangente categoria de preservação e conservação ambiental, encontram-se os Jardins Botânicos que, com suas diversas funções, têm papel fundamental à Educação Ambiental.

O caso aqui relatado, o do Jardim Botânico Benjamim Maranhão, em João Pessoa, Paraíba, tem proporcionado atividades de visitação, lazer e educação para turistas e visitantes que vão conhecê-lo. Através das atividades realizadas, majoritariamente de trilhas, a consciência ecológica e ambiental é instigada pelos monitores que fazem o acompanhamento das trilhas, proporcionando ao visitante maior conhecimento e interatividade com o espaço.

Mesmo com ações positivas encontradas, cabe deixar aqui considerações, tendo em vista novos projetos que podem ser desenvolvidos e/ou aperfeiçoados na área. O JBBM tem muito mais a ofertar, no que tange suas características ambientais, do que vem sendo utilizado. Ações mais incisivas de interpretação ambiental podem ser realizadas; parcerias institucionais e outras empresariais que favoreçam mais visitações ao local; práticas pedagógicas de outros e diversos campos de estudo (sociologia, economia, história); são apenas algumas sugestões.

No que tange a práticas turísticas, além do ecoturismo e do turismo pedagógico já realizados, pode-se pensar em turismo de aventura, podendo ser adequado a algumas atividades sem prejuízos ambientais; turismo de 
eventos, onde pequenos e médios eventos, principalmente com a temática ambiental, possam ser realizados ali; turismo científico e; turismo de experiência.

O Jardim Botânico Benjamim Maranhão é um espaço com muitos recursos naturais, precisando ser conhecido e apreciado, de modo a viabilizar maior consciência ambiental. Desta forma, sua capacidade de ser multiplicador de conhecimento e de ações sustentáveis será maximizada.

\section{Referências bibliográficas}

ANDRADE-LIMA, D.; ROCHA, M.G. Observações preliminares sobre a Mata do Buraquinho, João Pessoa, Paraíba. Anais do ICB - UFRPE, Recife, p.47-61, 1971.

BARBOSA, M.R.V. Estudo florístico e fitossociológico da Mata do Buraquinho, remanescente de mata atlântica em João Pessoa, Paraíba. 1996. Tese (Doutorado) - Universidade Estadual de Campinas, São Paulo, 1996.

BIESEK, A.S.; CARDOZO, P.F. Interpretação do Patrimônio Ambiental: o caso do Parque Nacional do Iguaçu (Foz do Iguaçu, PR). Revista de Cultura e Turismo. Ano 06, № 04, Out/2012.

BOTANIC GARDEN CONSERVATION INTERNATIONAL [BGCI]. Disponível: <http://www.bgci.org/resources/1528/>. Acesso em: 13 dez. 2014.

BRASIL. Decreto n. 21.264, de 28 de Agosto de 1885. Dispõe sobre denominação de logradouro público. Criação do Jardim Botânico de João Pessoa, 2000. Disponível em: <www.sudema.pb.gov.br/>. Acesso em 30 nov. 2014.

BRASIL. Decreto n. 98.181, de 26 de setembro de 1989. Declara de preservação permanente a floresta e demais formas de vegetação da área que descreve, $1989 . \quad$ Disponível em: $<$ http://www2.camara.leg.br/legin/fed/decret/1989/decreto-98181-26-

setembro-1989-439358-publicacaooriginal-1-pe.html>. Acesso em: 5 dez. 2015.

BRASIL. Lei n 9.795 de 27 de Abril de 1999. Dispõe sobre Educação Ambiental e institui a política Nacional de Educação Ambiental. Disponível em: <http://www.planalto.gov.br/ccivil 03/leis/L9.795.htm>. Acesso em: 9 jan. 2015.

BRASIL. Lei n. 12.651 de 25 de maio de 2012. Dispõe sobre a proteção da vegetação nativa; altera as Leis n. 6.938, de 31 de agosto de 1981, 9.393, de 19 de dezembro de 1996, e 11.428, de 22 de dezembro de 2006; revoga as Leis nos 4.771, de 15 de setembro de 1965, e 7.754, de 14 de abril de 1989, e a Medida Provisória no 2.166-67, de 24 de agosto de 2001; e dá outras providências. 2012. Disponível em: <http://www.planalto.gov.br/leis $>$. Acesso em: 28 nov. 2014. 
BRASIL. Política Nacional de Educação Ambiental, 1999. In: Brasil, Ministério do Meio Ambiente. Ministério da Educação. 3.ed. Programa Nacional de Educação Ambiental/ProNEA. Brasília, 2005.

CONSELHO Nacional do Meio Ambiente - CONAMA. Resolução n. 266, de 03 de Agosto De 2000. Dispõe sobre o uso das competências que the são conferidas pela Lei no 6.938, de 31 de agosto de 1981, 2000. Disponível em: $<$ http://www.mma.gov.br/port/conama/res/res00/res26600.html >. Acesso em: 20 jan. 2015.

DIEGUES, A.C. S. O Mito Moderno da Natureza Intocada. 4 ed. ACSA DIEGUES - SP: Hucitec/USP, 2004.

GADELHA NETO, P.C. Biodiversidade da Mata Atlântica. João Pessoa: Jardim Botânico Benjamim Maranhão, 2004.

GADELHA NETO, P.C. Trilhas ambientais do Jardim Botânico de João Pessoa: notas preliminares. João Pessoa: Jardim Botânico Benjamim Maranhão. 21p, 2006.

GADELHA NETO, P.C. Noções gerais sobre jardins botânicos. 2ed. João Pessoa: Jardim Botânico Benjamim Maranhão. 32 p, 2012.

IGNARRA, L.R. Fundamentos do Turismo. 2.ed. rev. e ampl. São Paulo: Pioneira Thomson Learning, 2003.

INSTITUTO CHICO MENDES [MMA/ICMBio]. Instrução Normativa 08/2008. Disponível em: <http://www.icmbio.gov.br/portal/images/stories/oque-somos/in082008.pdf>. Acesso em: 14 nov. 2014.

KINKER, S. Ecoturismo e conservação da natureza em parques nacionais. Coleção Turismo. Campinas, SP: Papirus, 2002.

LUCENA, E.R. Jardim Botânico Benjamim Maranhão. João Pessoa: Sudema, 2002.

MEDEIROS, R. et.al. Contribuição das unidades de conservação brasileiras para a economia nacional. Brasília: UNEP-WCMC, 2011. Disponível em: <http://www.mma.gov.br/publicacoes/areasprotegidas/category/51-unidades-de-conservacao $>$. Acesso em: 14 nov. 2014.

MILANO, M.S. Por que existem as unidades de conservação? In: MILANO, M.S. (org.). Unidades de Conservação: atualidades e tendências. Curitiba: Fundação O Boticário de Proteção à Natureza. p.193-208, 2002.

MINISTÉRIO DO TURISMO. Crescimento e Otimismo no setor Turístico. Disponível em $<$ http://www.dadosefatos.turismo.gov.br/dadosefatos/geral interna/noticias/d etalhe/20120822>. Acesso em: 14 nov. 2014.

MINISTÉRIO DO MEIO AMBIENTE [MMA]. Diretrizes para visitação em Unidades de Conservação. Secretaria da biodiversidade e florestas. Diretoria de áreas protegidas. Brasília: Ministério do Meio Ambiente, 2006. Disponível em: <http://www.mma.gov.br/publicacoes/areasprotegidas/category/51-unidades-de-conservacao >. Acesso em 7 nov. 2014. 
MINISTÉRIO DO MEIO AMBIENTE [MMA]. Primeiro relatório nacional para a Convenção sobre Diversidade Biológica. Brasília: MMA, 1998.

MINISTÉRIO DO MEIO AMBIENTE [MMA]. Convenção sobre Diversidade Biológica - CDB. Secretaria da biodiversidade e florestas. Programa Nacional de Conservação da Biodiversidade. Brasília: Ministério do Meio Ambiente, $2002 . \quad$ Disponível em: $<$ http://www.mma.gov.br/estruturas/sbf dpg/ arquivos/cdbport.pdf $>$. Acesso em 2 dez. 2014.

MOLINA, S. Turismo e ecologia. Bauru, SP: EDUSC, 2001.

MORSELLO, C. Áreas protegidas públicas e privadas: seleção e manejo. São Paulo: Annablume: Fapesp, 2001.

PAGANI, M.I et.al. As trilhas interpretativas da natureza e o ecoturismo. In: LEMOS, A. (ed.) Turismo: impactos socioambientais. São Paulo: HUCITEC, 1996.

PARAÍBA. Lei o 6.935 de 12 de Dezembro de 2000. Disponível em: $<$ http://201.73.83.244:8082/sapl/sapl documentos/norma juridica/6713 text o integral>. Acesso em: 20 nov. 2014.

PEREIRA, T.S.; COSTA, M.L.M.N.; JACKSON, P.W. Plano de ação para os jardins botânicos brasileiros. Rio de Janeiro: RBJB, JBRJ, BGCl, 2004.

REDE BRASILEIRA DE JARDINS BOTÂNICOS [RBJB]. Jardins Botânicos Brasileiros. Disponível em: <http://www.rbib.org.br/jardins>. Acesso em 30 out. 2014.

ROCKTAESCHEL, B.M.M.M. Terceirização em Áreas Protegidas: estímulos ao ecoturismo no Brasil. São Paulo: SENAC, 2006.

RUSCHMANN, D. Turismo e planejamento sustentável. 11.ed. Campinas, SP: Papirus, 2004.

SANTOS, M.M.; ALAMO, J.B. Del. Evaluación de la interpretación de parques nacionales: o saber que hacemos, como lo hacemos y como mejorarlo. Boletín de interpretación. N. 23. Espanha. s/d. Disponível em: $<$ http://www.interpretaciondelpatrimonio.com/boletin/index.php/boletin/article/ viewFile/247/247>. Acesso em: 14 jun. 2015.

SILVA, D. L. da. Turismo em Unidades de Conservação: contribuições para a prática de uma atividade turística sustentável no Parque Nacional dos Lençóis Maranhenses. Dissertação de Mestrado. Centro de Desenvolvimento Sustentável, Universidade de Brasília, Brasília, 2008.

SILVA, D. M. da. A caracterização da Interpretação Ambiental pelo conteúdo das mensagens: análise da atividade de um guia do Parque Estadual Mata dos Godoy (Londrina/PR). 2012. 92 p. Dissertação de Mestrado. Universidade Estadual de Londrina, Londrina, 2012. Disponível em: $<$ http://www.iap.pr.gov.br/arquivos/File/Pesquisa\%20em\%20UCs/Autorizaca o e Projetos 2014/projeto 001.pdf>. Acesso em 19 ago. 2015. 
SISTEMA Nacional de Unidades de Conservação da Natureza - SNUC: a lei n. 9.985, de 18 de julho de 2000. Brasília: MMA/SBF, 2000, (32 p.). Disponível em: <http://www.planalto.gov.br/leis >. Acesso em 13 dez. 2014.

\section{SUPERINTENDÊNCIA DE ADMINISTRAÇÃO DO MEIO AMBIENTE} [SUDEMA]. Plano de manejo do jardim botânico de João Pessoa. João Pessoa: SUDEMA, 2003.

TILDEN, F.. Interpreting our heritage. The University of North Carolina Press. 3 $3^{\mathrm{a}}$ ed., 1957.

VASCONCELLOS, J.M. O. Trilhas interpretativas: aliando educação e recreação. Anais do Congresso Brasileiro de Unidades de Conservação. Curitiba: IAP, UNILIVRE, REDE PRÓ-UC, v.1, p.465-477, 1997.

WILLIAMS, P.E.; GILL, A. Questões de gerenciamento da capacidade de carga turística. In: THEOBALD, W. (ed.) Turismo global. São Paulo: Ed. SENAC São Paulo, 2001.

\section{Notas}

1 Entende-se por segmentos turísticos ou segmentação de mercado, o ato de identificar e agrupar grupos distintos de compradores que podem exigir produtos e/ou compostos de marketing separados (KOTLER, 1996 apud IGNARRA, 2003, p.56).

2 Biodiversidade significa a variabilidade de organismos vivos de todas as origens, compreendendo, dentre outros, os ecossistemas terrestres, marinhos e outros ecossistemas aquáticos e ou complexos ecológicos de que fazem parte; compreendendo ainda a diversidade dentro de espécies, entre espécies e de ecossistemas (MMA, 2000).

3 Ecoturismo é o segmento da atividade turística que utiliza, de forma sustentável, o patrimônio natural e cultural, incentiva sua conservação e busca a formação de uma consciência ambientalista por meio da interpretação do ambiente, promovendo o bem-estar das populações (Disponível em: <http://www.turismo.gov.br/turismo/programas acoes/regionalizacao turismo/estruturacao segmentos/ecoturismo.html>. Acesso em $10 \mathrm{dez}$. 2014).

${ }^{4}$ Desenvolvimento Sustentável é entendido como um processo de transformação no qual a exploração dos recursos, a direção dos investimentos, a orientação do desenvolvimento tecnológico e a mudança institucional se harmonizam e reforçam o potencial presente e futuro, a fim de atender as necessidades e aspirações humanas (CONFERENCIA DE LAS NACIONES UNIDAS SOBRE EL MEDIO AMBIENTE Y EL DESARROLLO [CNUMAD]. Nosso futuro comum. $2^{\circ}$ ed. Rio de Janeiro: FVG, 1991).

5 Entende-se Educação Ambiental como processo por meio do qual o indivíduo e a coletividade constroem valores sociais, conhecimentos, habilidades, atitudes e competências voltadas para conservação do meio ambiente (BRASIL, 1999).

${ }^{6}$ Compreende-se por visitação o aproveitamento e utilização da Unidade de Conservação e demais áreas protegidas com fins recreacionais, educativos, entre outras formas de utilização indireta dos recursos naturais e culturais (MMA, 2006).

7 Isso porque o primeiro e mais antigo jardim botânico do Brasil foi implantado em Recife, no período da dominação holandesa (1630-1654), e reunia espécimes da flora coletadas durantes as expedições ao sertão nordestino (RBJB, 2013), hoje apenas se tem registro de sua ocorrência.

8 É considerado um dos principais pontos turísticos da capital paranaense e um dos mais belos cartões postais de Curitiba. Conhecido por sua bela estufa e seu jardim geométrico. Em 2007, o ponto turístico foi um dos monumentos mais votados numa eleição para a escolha das Sete Novas Maravilhas do Brasil, realizada pelo site Mapa-Mundi (Jardim Botânico de Curitiba, 2013. Disponível em: <http://jardimbotanicocuritiba.com.br>. Acesso 
em: 12 nov. 2014). Tornou-se referência turística nacional. Quanto aos jardins botânicos e segundo a classificação de jardins exposta por Pereira (2004) este se enquadra no tipo jardim ornamental.

9Trilhas interpretativas são caminhos preestabelecidos com diferentes formas, comprimentos e larguras, que possuem o objetivo de aproximar o visitante ao ambiente natural, possibilitando seu entretenimento ou educação através da sinalização ou de recursos interpretativos (SALVATI, S.S.. Trilhas: conceitos, técnicas de implantação e impactos, 2001).

10 O Programa de Desenvolvimento do Turismo no Nordeste (PRODETUR/NE) é um programa de crédito para o setor público (Estados e Municípios) que foi concebido tanto para criar condições favoráveis à expansão e melhoria da qualidade da atividade turística na Região Nordeste, quanto para melhorar a qualidade de vida das populações residentes nas áreas beneficiadas. Este programa é financiado com recursos do BID e tem o Banco do Nordeste como Órgão Executor (BANCO DO NORDESTE, 2013. Disponível em: <http://www.bnb.gov.br/content/aplicacao/PRODETUR/Apresentacao/gerados/apresentacao .asp>. Acesso em: 16 dez. 2014).

llana Barreto Kiyotani: Universidade Federal da Paraíba. João Pessoa, PB, Brasil.

E-mail: ilana.kiyotani2@gmail.com

Link para o currículo Lattes: http://lattes.cnpq.br/7828074743842118

Fabiana Gomes Sousa: Universidade Federal da Paraíba. João Pessoa, $\mathrm{PB}$, Brasil.

E-mail: fabiana.tur@hotmail.com

Link para o currículo Lattes: http://lattes.cnpq.br/3041538273887359

Amada Gama Tavares: Universidade Federal do Rio Grande do Norte, Natal, RN, Brasil.

E-mail: amada.tavares@hotmail.com

Link para o currículo Lattes: http://lattes.cnpq.br/5362262595958155

Data de submissão: 27 de fevereiro de 2015

Data de recebimento de correções: 31 de agosto de 2015

Data do aceite: 02 de setembro de 2015

Avaliado anonimamente 